\title{
ZBTB17 wt Allele
}

National Cancer Institute

\section{Source}

National Cancer Institute. ZBTB17 wt Allele. NCI Thesaurus. Code C52339.

Human ZBTB17 wild-type allele is located within 1p36.2-p36.1 and is approximately $34 \mathrm{~kb}$ in length. This allele, which encodes zinc finger and BTB domain-containing protein 17, plays a role in the mediation of both gastrulation and the cell cycle. 